\title{
Youth Farming and Nigeria's Development Dilemma: The Shonga Experiment
}

\author{
Joseph Ayodele Ariyo and Michael Mortimore
}

Abstract Youth farming is undergoing a transformation in Nigeria as the incentive framework for small-scale farming changes. Rural-urban migration, rural poverty, education and the new opportunities it affords, and technological change are among the drivers of this transformation. Meanwhile, as the demand for food commodities increases with urbanisation, an exodus of labour from the countryside threatens food sufficiency at the national level. Agrarian policy faces a difficult threefold choice between state-supported large-scale commercial farming, training young farmers for small-scale commercial farming, and continuing present policies of improving incentive structures for small-scale peasant farmers. In Kwara State, the Shonga experiment in large-scale commercial methods, involving 13 Zimbabwean farmers, is viewed through the lens of youth farming and the necessary transfer of national food provisioning to a new generation of producers. It is found that youth farming is likely to be as dependent on state subsidies as the Zimbabueans are.

\section{Introduction}

Context is everything in Nigeria's complex economic, social, and environmental systems. Agricultural development faces major challenges including a very large and rapidly growing population (140 million plus), a growing scarcity of cultivable land, urbanisation, changing food preferences, and dynamic internal markets. Projected into the future, these trends raise many questions for policymakers. Nigeria is the giant of West Africa and its trajectories seem likely to be replicated in other countries (OECD 2000).

In this article, we first summarise the agrarian policy dilemma facing Nigeria, and then provide a short narrative of an experiment in large-scale farming in the 'middle belt' (Kwara State). We then focus on an associated programme of youth farming that is intended to build a bridge between it and the small-scale peasant farming which still employs an overwhelming majority of rural Nigerians, and still feeds the nation with its major food staples (yams, cassava, sorghum, pearl millet and maize). Scale and technology, organisation and marketing play critical roles. We identify an emerging 'generation gap' in the agricultural labour force, and ask whether youth farming is a competent candidate for transferring the responsibility of feeding the nation in the next generation.

\section{The dilemma of agrarian policy 2.1 A brief history}

Agrarian policy has been a critical issue in Nigerian economic development since the imposition of colonial rule at the beginning of the twentieth century. Small-scale peasant farming has been at the centre. Following independence in 1960, public policy increasingly focused on 'modernisation', which, it was believed, could increase rural incomes and productivity (Helleiner 1966; Forrest 1993; Mustapha and Meagher 2000). However, the desired transformation remained elusive, and the search intensified for ways of achieving food security at the national level.

From the 1970s onwards, an oil boom in Nigeria decoupled food production from demand, by making it possible to import cheap food from abroad - a strategy which still continues. Meanwhile agricultural exports (groundnuts, cotton, cocoa and palm oil) lost their competitive edge in world markets owing to an overvalued 
currency. It is not surprising that there was 'a pervasive feeling at the time that the country was on the cusp of an agrarian crisis' (Mustapha and Meagher 2001). One federal intervention followed another yet failed either to bring about the desired 'modernisation' of agriculture or to slow down a growing exodus of labour to the cities. Projections of food deficits were made by various experts - one study predicted a deficit of 6.6 million tons of grain equivalent by 1985 . Yet as records later showed, Nigerian farmers 'were to confound these experts and undermine their scientific pretensions' (Forrest 1993, cited in Mustapha and Meagher 2001).

After the introduction of structural adjustment policies in 1986, negative perceptions of the performance of the agricultural sector persisted, influenced by the volume of food commodity imports and the high prices of fertilisers. However, according to FAOSTAT data, food production kept up with the rate of population growth through the 1990s, not only of yams and cassava (which did extremely well) but even of millet and sorghum, which increased from as early as 1978, though more slowly. Evidence from FAO statistics suggests that in West Africa, even under conditions of low and erratic rainfall, the production of food commodities has kept up with population growth in the long term. ${ }^{1}$ During this period, the food commodity markets in Nigeria, driven by urbanisation, were strong (Ariyo et al. 2001). But there was (and still is) much poverty, reducing demand. The best construction of these data, it has been argued, is that demand rather than supply factors constrain output at the macro-scale, especially where smallholder economies lack export markets for staple foods (Mortimore 2003).

Nigerian agrarian policy, since early colonial times, had been predicated on small-scale peasant farming with two goals: subsistence production (or food security) and a marketable 'surplus' - originally for export - for which economic incentives were provided. Continuing belief that this strategy is failing has engendered increasing interest in alternative ways of promoting new technologies that are popularly considered to be more 'efficient'. The new policy strategy (especially in Kwara State) is to make access to land and credit easier for individuals or corporations using industrial/commercial farm technologies. The necessary subsidies and privileges can be managed better where there is a 'bankable' agricultural project (in other words, transferring agriculture from the informal to the formal sector). Much faith is placed in the technologies of commercial agriculture spreading across the country from the enclaves currently being created. ${ }^{2}$ This is despite the fact that the World Bank is now emphasising making smallholder agriculture more commercially oriented (World Bank 2007).

The implication is that the state has a pivotal role to play in the growth and sustainability of commercial agriculture (Daramola 2010). This is particularly the case in developing countries, where tenure systems may impede access to large tracts of land, infrastructure is rudimentary and commercial banks are jittery about providing support for agriculture. The activities of the Kwara State government in promoting commercial agriculture reflect these requirements.

\subsection{Agrarian livelihoods}

Farming is not a closed system, but from the perspective of rural families, it competes with off-farm income opportunities, especially those accessed through short- or longer term migration. Long ago, such mobility became a feature of rural life, attracting youths in particular because their parents had year-round commitments at home. The movement of labour and capital between regions and countries characterised economic development in the West African region (Mabogunje 1972). For example, landless young men from densely populated districts migrated to centres of export agriculture as tenant farmers (Udo 1975). In semi-arid areas, with a long dry season, and where variable rainfall caused unpredictable crop yields, migration towards the coastal centres had long supported family incomes (Rouch 1956; Prothero 1959). In the drought cycles of the 1970s and 1980s, migration enabled access to new opportunities created by the oil boom in Nigeria (Mortimore 1989). Young people were attracted to off-farm incomes, urban jobs, and opportunities that their education (which their parents had not enjoyed) brought within their reach. Even those lacking modern education could participate in migratory jobseeking in the urban informal sector, through a natural evolution of the short-term (or 'circular') migrations of the past. 
It is in this broader context of livelihood aspirations that Nigeria's agri-food sector evolved in the later decades of the twentieth century. Although generalisation is risky, it may be said that most food commodity production remained in the hands of a slowly ageing population of farmers (women or men), using hand technology, conserving indigenous knowledge, and relying on family labour. In some parts of the country, shortages of farm labour were noted (e.g. in Kwara State, which was within easy reach of the rapidly growing urban centres in the south-west, and in some hilly districts where much labour is required to maintain soil conservation structures). At the same time, educated young people (women as well as men) came to despise rural life with its hard and dirty work, and low rewards. Thus the generation gap, supported by a negative attitude, has come to threaten the food security of the nation.

The dilemma for agrarian policy has thus been enlarged from a search for appropriate technologies with which to facilitate the 'modernisation' of small-scale peasant farming, to the challenge of transferring the foodproducing sector from an ageing and mostly poor farm population to a new generation of producers. To do this, new attitudes as well as new technologies, and greater investment finance, are needed in the sector.

Fundamental drivers of this transformation will be demographic. Besides the ageing (and retirement) of an increasing proportion of the existing farm population, as already noted, we may expect, as a consequence of prevalent high human fertility and the falling child mortality experienced in the first stage of the 'demographic transition', a huge increase in job seekers (a 'demographic dividend' if they can be found productive employment). We may also expect a slowing and eventual decline of rural population growth, as a majority of the population becomes urbanised. Estimates of the level of urbanisation in Nigeria (defining 'urban' as settlements with 20,000 or more inhabitants) vary widely from a UN estimate of 49 per cent to a more modest, research-based estimate of 30 per cent, which reflects a falling off in urban population growth in recent years (Potts 2012). ${ }^{3}$

The alternative to modernising small-scale agriculture is to replace it with large-scale commercial farming, targeting the growing numbers of urban consumers, and benefiting from rising global prices of food commodities. Advocates of prioritising small-scale agriculture point to higher average yields per hectare achieved in labour-intensive systems (predicted by Boserup 1965), supposed more efficient use of production factors through self-employment on one's own fields, and the beneficial linkages between agriculture and other sectors of the economy through multiplier effects (Mellor 1995). Since poverty is deepest in rural areas, its reduction there will have the greater impact. Advocates of large-scale farming throw doubt on the data and methods used to support productivity and efficiency gains, and point to the advantages of large scale in obtaining and using capital, knowledge, insurance, mass marketing, etc. (Collier and Dercon 2009).

A renewed interest in large-scale agriculture in Nigeria reflects, among other things, deregulated agricultural markets favoured by current economic policy, the large amounts of private investment capital available in the country (seen in, for example, road transport, commodity importation, food processing plants), and energetic advocacy at international level, as well as frustration with the poor results of many interventions intended to boost the small-scale sector. Moreover, the arrival of the 'superfarm' - a foreign lease on vast areas of allegedly 'unoccupied' land in order to produce food (or other commodities) for export to the investing country - has added to the renewal of interest in large-scale farming.

Again, agriculture needs to be understood in context. In the transformation of the industrialurban countries in the nineteenth and early twentieth centuries, the surplus labour created by large-scale agricultural systems was absorbed - if at a cost - by the new industrial enterprises, themselves labour-intensive. In tropical Africa, fledgling industries are few, they have been adversely affected by global recession and other factors, and technologies are no longer labourintensive. The choice of an agricultural development strategy cannot ignore its employment implications. It will depend on balancing priorities for the sector between filling consumers' mouths on the one hand and supporting producers' livelihoods on the other. These considerations are relevant in Nigeria, where the demographics are especially compelling. 


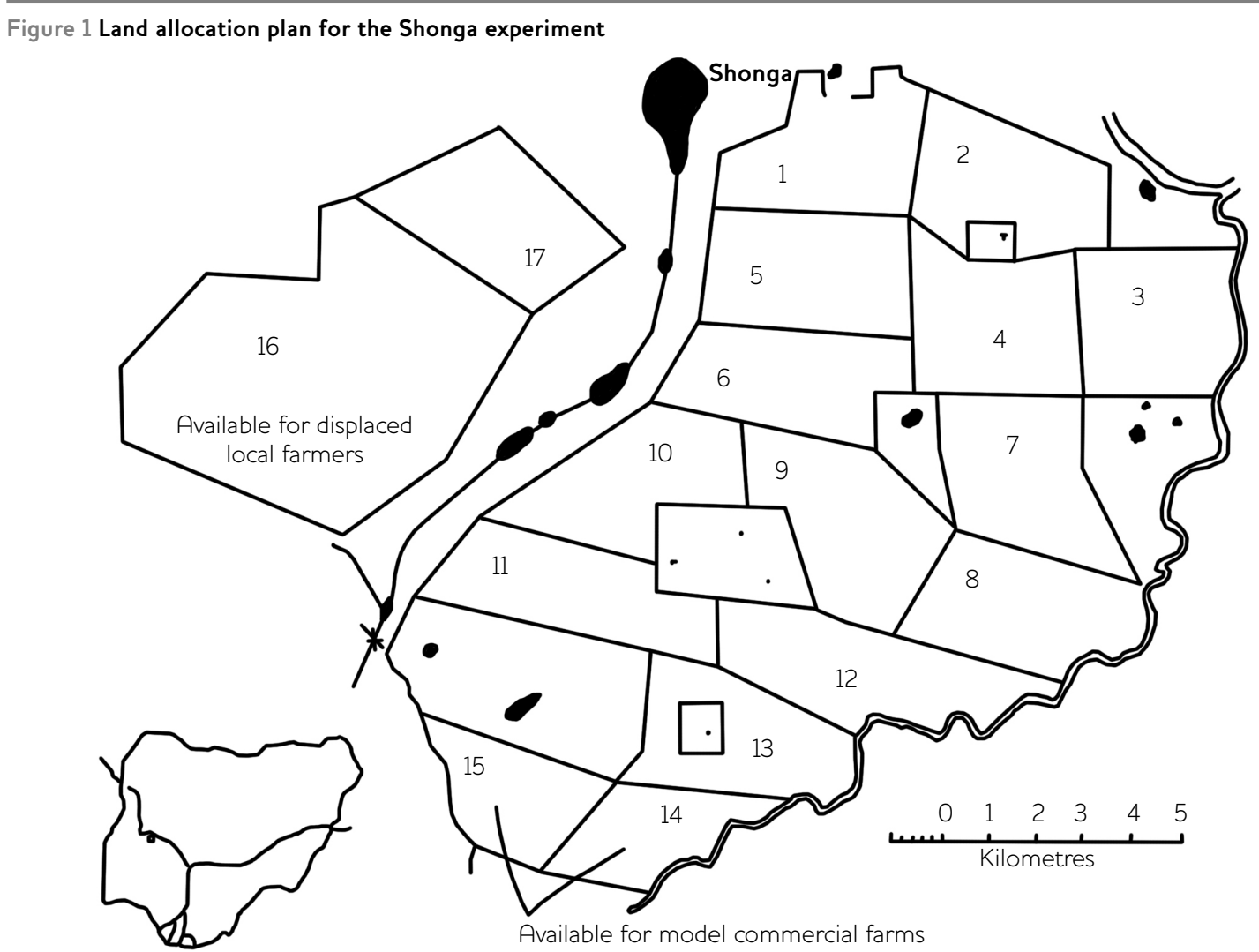

Source Kwara State Ministry of Lands and Surveys.

\subsection{Kwara State}

The government of Kwara State is carrying out an experimental development with 13 Zimbabwean farmers at Shonga, adjacent to the River Niger. The stated purpose of the 'experiment' (as the government calls it) is to test the feasibility of large-scale technologies and production systems in Nigerian conditions. Large-scale farming is not unknown in Nigeria, though little analysis of the scattered and diverse projects is available. But a high level of interest in acquiring title to large agricultural holdings, on the part of individuals and corporations, suggests potential for replication if the experiment is successful.

However, the state government has not abandoned a small-scale modernisation strategy for agriculture, and has committed itself to several programmes, including a 'back to the land' initiative for young people which was a failure. The initiation of the Shonga 'experiment', which receives various forms of government support, has been followed by popular demand for support of technological change at smallholder scale. One scheme is specifically linked to the Shonga 'experiment' - setting aside some land, and providing some training (in which the large-scale farmers will participate), for selected and financially assisted local young people.

\section{The Shonga Farms in Nigeria - narrative of an intervention}

In 2004 Governor Bukola Saraki of Kwara State, with political support from the Federal

Government of Nigeria, and diplomatic support from the British government, invited a five-man delegation from the Commercial Farmers' Unions of South Africa and Zimbabwe for a one-week factfinding visit to his state. The visit, which was paid for by the Kwara State government, led to the signing of a Memorandum of Understanding $(\mathrm{MoU})$ between Kwara State and the Zimbabwean farmers. A year later, 13 farmers arrived at Shonga to take up long leases, each of 1,000 hectares, for commercial (large-scale) farming (see Figure 1).

The key components of the MoU commit the Kwara State government to provide (i) suitable land close to the River Niger to facilitate yearround farming through irrigation, 
(ii) infrastructure such as access roads to the farms and electricity, (iii) access to funds, and (iv) assistance to the farming enterprises in obtaining from the federal authorities a pioneer status, which brings exemptions from import duties on agricultural equipment and from taxes on turnover. There are three obligations of the commercial farmers in the MoU. They are expected to (i) incorporate each farm enterprise with US\$80,000 share capital, (ii) contribute 1 per cent of their gross turnover to a community trust fund, and (iii) provide instruction at least once a month in the state farm training institute in Shonga (and later, Malete).

The land which was allocated to the new arrivals was a patchwork of arable fields, long ('bush') fallows and unused woodland, with scattered small villages. In addition to the 13,000 hectares leased to the commercial farmers, an additional 4,656 hectares were acquired for compensation of local farmers who lost land and for setting up 'model commercial farms' for individuals nominated by the Emir of Shonga. Compensation in cash and kind (bicycles and inputs) was paid to 1,990 claimants. The villages, however, were not affected, and no one had to move residence; a 'buffer zone' of $500 \mathrm{~m}$ radius around each preserved the rights of cultivators (see Figure 1).

The 13 farms were partially cleared, supplied with road and electricity infrastructure, and organised into enterprises specialising in poultry (four farms), dairying (four farms) and crops only (five farms). The first farming season was in 2006. By 2011 broiler chicken pens, an abattoir and dressing plant, milk processing and storage had been built, with a sideline in yoghurt production. Cattle breeding had commenced, and sprinkler irrigation had been partially completed on one farm. Cassava processing into fufu (flour for retailing) was planned. The major crops tried thus far included soyabeans, maize, sorghum, cowpeas and cassava. Rice

development was held up by the lack of irrigation equipment. Houses, farmyards and sheds for crop and equipment storage had been designed and constructed by the farmers themselves.

Access to bank loans guaranteed by the Kwara State government was critically important as none of the farmers were able to bring capital from Zimbabwe. The state government mobilised equipment to assist with the removal of large trees. However, land clearance stopped at about 50 per cent of the intended cropped area, and to achieve an adequate threshold of profitability, a larger cultivated fraction is required. Loans for this and for other expansion have been slow to come, especially for enterprises for field crops, which are the least viable, because it has not been possible to date to realise the potential for rice production. In 2011, three of the five banks in the consortium were classified as 'distressed' by the Central Bank of Nigeria, sharply worsening the capital supply for that season. The recruitment of an additional bank, with experience of agricultural lending in South Africa, is hoped to alleviate the financial situation in 2012 .

All the products are sold in Nigerian markets. Broiler chicken capacity of 100,000 per month is directed to chain eateries, mainly in Lagos; the milk is sold to a powdered milk processor in Lagos; yoghurt is sold locally and in the state capital, Ilorin; soyabeans and the grain crops are partly fed to livestock (maize, sorghum and cowpeas) and partly sold outside Shonga; and cassava demand was initially buoyant in southern Nigeria including a buyer from the south-east who planned to build a processing plant nearby, to reduce transportation costs.

However, notwithstanding the relatively equable climate of the Southern Guinea Savanna agroecological zone, risk exposes some enterprises beyond the apparent capacity of the banks to underwrite. A sudden downturn in the cassava market in 2011 has left at least one producer with unsold, rotting crops in the field, and a shortage of rainfall in mid-season damaged the maize crop. The soils are less fertile than initially assessed, and maize has not responded well; some dairy producers prefer to buy fodder maize from local farmers. Poultry enterprises are doing best, but the costs of running highly sophisticated, airconditioned plant are adversely affected by electricity outages, when generators have to be used. Farmers compound the chicken feeds themselves, and use the best available day-old chicks (from a hatchery in Ibadan, 220km away) to obtain maximum growth rates. Milk producers suffered losses when flooding closed down the Lagos processing plant for a month in $2011 .{ }^{4}$

\section{Youth farming}

The pursuit of large-scale commercial agriculture by the Kwara State government in recent years is 
predicated on the notion that the pathway to socioeconomic development is to create a class of commercial farmers who will utilise the large expanse of arable land and equitable climate with which Kwara State is endowed. It all began with the electioneering campaign promise which Dr Bukola Saraki made in 2003 when he was seeking to be elected governor. When he won the election, he was immediately confronted by a horde of unemployed and restless young people who had to be turned into 'useful citizens'. So, in his first year as governor, he initiated a 'back-to-the-land' programme involving setting aside large tracts of land in many locations across Kwara State, and the provision of loans for land clearance and procurement of improved seeds, fertilisers and agrochemicals. But was this what the youth wanted?

Most of the targeted young people did not turn up to claim their entitlements. Instead, a few farmers and many non-farmers got the package incentives and re-sold them outside Kwara State. The overall performance of the 'back-to-the-land' programme was rated very poor at the end of the first year.

Many of the 300 young people who were the target of the scheme had never farmed before or had been off the farm for a long time. So it was no surprise that they did not respond to an agricultural scheme based - as they saw it - on hoe-and-cutlass technology. A new programme of youth empowerment through agriculture was launched which aims to train young people in all aspects of commercial farming. Two such training centres have been established, one in Shonga itself, and the other in Malete, further south in Kwara State. After the training, Kwara State promises to assist the young farmers to gain access to bank credit, and land, in their respective local government areas. These young people are expected to become the backbone of commercial agriculture in the state. The programme has not yet been thoroughly assessed.

5 Financial and land constraints in youth farming Finance is the major constraint, and unless they have advocates in the administration, the young farmers have great difficulties in accessing the loans to which they are supposed to be entitled. Some trained young farmers (five per Local Government Area (LGA)) who had already obtained land, and were guaranteed by very senior state civil servants, got financial assistance (US\$1,333 each) in 2010. Financial allocations to trained young farmers which were captured in the 2010 budget were rolled over into the 2011 budget. It was expected that an intervention by the federal government and the Central Bank of Nigeria through a 'commercial agricultural credit scheme' would materialise. Some money from this scheme came to Kwara State late in 2011; and disbursements were made to some trained young farmers who belong to registered cooperatives (US $\$ 1,994$ per farmer). There is a provision for young farmers in the 2012 budget proposal.

No specific financial mobilisation by the state government through LGAs has been made. A controversial LGA/state government joint account system is a major constraint to LGAs, which complain that they could execute more development projects if their allocations from the federation accounts go directly to them.

Without the state government's intervention, access to land may be a problem in some LGAs. In Shonga, however, the land for nominated young farmers to open community 'model commercial farms' has already been acquired by the government (see Figure 1, farms 14 and 15). To acquire land for any purpose, the state governor has to invoke the Land Use Act of 1978, under which suzerainty is vested in him, and compensation has to be paid for any improvements on the land. Due process must be effected. To accommodate the young farmers in locations scattered about the state, costly procedures and delays are inevitable.

It follows from these constraints that both the scale and the momentum of the youth farming schemes are insufficient for them to fulfil the role of new technology users and diffusers. Furthermore, the dependence of trained young farmers on external sources of financial support is proportionately as great as that of the largescale commercial farmers. It appears that no attempt has been made to involve the commercial banks in youth farming schemes. There is no enabling law to which young farmers can have recourse when denied access to farmland. Waiting for customary inheritance of family farms is unacceptable. It seems clear that without a legal enactment (within the provisions of the Land Use Act), to entitle young farmers to hold land on a long lease, the state government will not be able to accelerate the youth farming programme. 
Table 1 Changes in land use classes in three northern Nigerian states, from 1976/8 to 1993/5 (per cent of total area)

\begin{tabular}{|c|c|c|c|}
\hline Category & Adamawa & Jigawa & Kano \\
\hline Intensive rain-fed agriculture & from 23 to 22 & from 37 to 69 & from 86 to 87 \\
\hline Extensive rain-fed agriculture & from 25 to 30 & from 39 to 6 & from 3 to 10 \\
\hline Flood plain agriculture & from 1 to 3 & from 8 to 10 & from 1 to 2 \\
\hline $\begin{array}{l}\text { Uncultivated (grass, shrubs, } \\
\text { trees, wetland) }\end{array}$ & from 49 to 41 & from 15 to 12 & from 8 to 9 \\
\hline Others & from 2 to 4 & from 1 to 3 & from 2 to 2 \\
\hline $\begin{array}{l}\text { State population density } \\
\text { (sq km in 1993) }\end{array}$ & 57 (= low) & 121 (= medium) & 274 (= high) \\
\hline
\end{tabular}

Source Geomatics International (1998).

Most of the nearly 300 young men and women trained under the 'youth empowerment programme' have thus not yet enjoyed the support (in land and credit entitlements) that was promised them by the state. The 'community model commercial farm' scheme at Shonga has not taken off. No land has been allocated to anyone from the 1,200 hectares set aside for this purpose. Off-the-record comments among state officials imply that there are no interest groups at the state or local level pushing for the implementation of the programme. Thus it appears that the potential for uptake of new technology in other parts of Kwara State is in jeopardy.

\section{From context to content}

Land use in northern Nigeria is variable from place to place and constantly changing. In three states, representing a range of population densities, land use data show increasing areas under cultivation (see Table 1$).^{5}$ The general direction of conversion was from uncultivated to extensive cultivation and from extensive cultivation to intensive cultivation, with a strong correlation with population density.

Extensive ('shifting') cultivation is normally introduced on land belonging to the community or to the family. Conversion to intensive cultivation is done on land which is securely held through inheritance, purchase, allocation or prior use. When the supply of new land was abundant, the strategy was to expand output by taking in more farmland. There was a rapid response to the demand for export crops. In many (though not yet all) areas, there is little unclaimed land remaining. Intensification is an imperative. But it requires capital; as family members depart for the city, labour has to be hired, and as soil nutrients are steadily taken away, compensating inputs must be purchased. Thus, agriculture is becoming less to do with subsistence and more of a business. And this means that finance is a major driver throughout the sector, to an extent not experienced before. This is relevant to both large-scale farming and youth farming.

Youth farming, and agricultural development in general, are embedded in the complex, interactive system that is modern Nigeria. Rural population growth means more labour or skills as well as more consumers. Urbanisation, however, means less rural labour or skills but even more consumers. That Nigeria has already urbanised to the extent of 30 per cent ${ }^{6}$ of its massive population (Potts 2012) represents an unprecedented opportunity for the commercialisation of the sector - with rising commodity prices motivating investment in new technologies. There is a danger that governments will become stuck in outdated paradigms and find themselves unable to adapt policy to such rapid change. One has only to observe the burgeoning roadside food markets all over the federation to be convinced of both the achievements of, and the opportunities for commercial participation. Yet the clamour continues for help from the public sectormore fertilisers, petrol subsidies - reflecting a contradictory attitude of dependency.

Kwara State seems to be pursuing three models of developing commercial agriculture. The first, and newest, is the high-profile, subsidised, largescale commercial farm model in Shonga, which is 
also being replicated around the state. ${ }^{7}$ Whether this model can succeed without government subsidies remains to be seen. The second model involves training young people and empowering them with state support to become commercial farmers. Because of the political capital invested in this programme, a link with the Shonga commercial farms was built into its design. Land was allocated for nominated young farmers, and provision for training by the commercial farmers was included in the Shonga MoU. The third is the old model of providing a modicum of incentives, such as subsidised inputs, to smallholder farmers and leaving them to their own devices to move agriculture forward. It is not uncommon to hear contempt for this strategy or at best an official nonchalance about its capacity to achieve transition (or revolution) in agriculture. Such attitudes originate probably in its inability so far to produce rapid productivity growth. In Shonga, some technology transfer - and informal shared learning - with the commercial farmers is taking place: for example, soyabean is being adopted by smallholders, and cattle breeding methods exchanged with a pastoralist group.

Youth farming will not provide a resolution of the policy dilemma without stronger backing in the political economy of Kwara State. Not only are these three models contesting the state's resources, but there are strong economic and political interests involved. Young people are seen as a consistently underperforming element in the landscape of rural development. Efforts to realise their potential go back to the farm settlements (inspired by the Israeli kibbutzim) in the former Western Region during the 1960s (FAO 1966). Is it because the wrong paradigm (modernisation through technological transfer)

\section{Notes}

1 FAOSTAT, Rome: Food and Agriculture Organization of the United Nations, faostat.fao.org (accessed 26 August 2012).

2 Large-scale farming is not new to Nigeria, however. Individuals (including a former president) and corporations (such as breweries) have been accumulating land through purchase and grants from state governments for many years.

3 Urban populations are notoriously difficult to estimate owing to poor census records and volatile movements.

4 The Shonga experiment has attracted much is receiving all the emphasis? Or is it due to halfhearted political commitment to remodelling the incentive structure?

There is a sharp paradox in the disdainful attitude held towards agriculture by many Nigerian young people on the one hand, and the enthusiasm for entrepreneurial activity evident in markets, value chains, spatial interaction, cities, and households on the other. Agricultural education has traditionally stressed science and technology, at all levels. What does an agriculture graduate expect to live by? Informal enquiries show that very many expect to end up behind a desk, not farming. There is therefore an urgent need to reexamine the place of entrepreneurship in agricultural training (Falola 2008). In a modern free market economy, to continue expanding public sector employment is anachronistic. For an inexperienced graduate to offer advice to a middle-aged farmer-entrepreneur is absurd. And it was shown many years ago that older farmers are more, not less innovative - because they know the markets and can afford to invest (Tiffen 1976). Reference was made earlier to the possibility that limited demand, not supply, forms the biggest impediment to agricultural development. This hypothesis is supported elsewhere, as helping to explain why the Asian green revolution has not taken off in Africa (Djurfeldt et al. 2004). If so, how long must we wait for the 'demographic dividend' to express itself through improved incomes and more efficient markets? Value chains, institutions, and supporting infrastructure need to be prioritised in West African development policy (Bolwig et al. 2009). Young people (as we have suggested) may find such an approach more relevant to their needs and aspirations.

interest; see, for example Mustapha (forthcoming).

5 An anomalous trend in Kano State reflects the impact of urbanisation and speculation in land after cultivation peaked in the 1970s. For more detail, see Mortimore and Turner (2005).

6 The UN estimate is 49 per cent.

7 Eighteen projects varying in size from 11 to 15,000ha are registered with the Kwara State Ministry of Agriculture and Natural Resources. Large-scale farming projects are found in other states, including Nassarawa. 


\section{References}

Ariyo, J.A.; Voh, J.P. and Ahmed, B. (2001) LongTerm Change in Food Provisioning and Marketing in the Kano Region, 1960-2000, Kano-Maradi Study of Long-Term Change: Niger-Nigeria Series, Working Paper 34, Crewkerne, UK: Drylands Research

Bolwig, S.; Cold-Ravnkilde, S.M.; Rasmussen, K.; Breinholt, T. and Mortimore, M. (2009) Achieving Sustainable Natural Resource Management in the Sahel after the Era of Desertification - Markets, Property Rights, Decentralisation and Climate Change, DIIS Report 2009:07, Copenhagen: Danish Institute for International Studies

Boserup, E. (1965) The Conditions of Agricultural Growth, London: Allen and Unwin

Collier, P. and Dercon, S. (2009) 'African Agriculture in 50 Years: Smallholders in a Rapidly Changing World?', Expert Meeting on How to Feed the World in 2050, Rome, Food and Agriculture Organization of the UN

Daramola (2010) 'Public-Private Partnership in Commercial Agriculture in Nigeria: Issues, Constraints and Prospects', keynote paper presented at a national seminar at ARMTI, Ilorin, 2 December 2010

Djurfeldt, G.; Holmén, H.; Jirström, M. and Larsson, R. (2004) The African Food Crisis. Lessons from the Asian Green Revolution, Wallingford: CABI Publishing

Falola, J.A. (2008) 'Presidential Address to the Nigerian Geographical Association', Nigerian Geographical Journal

FAO (1966) Agricultural Development in Nigeria, 1965-1980, Rome: Food and Agriculture Organization of the UN

Forrest,T. (1993) Politics and Economic Development in Nigeria, Boulder CO: Westview Press

Geomatics International (1998) The Assessment of Vegetation and Land Use Changes in Nigeria between 1976/78 and 1993/95, Ibadan: Forestry Management Evaluation and Coordinating Unit (FORMECU), Federal Government of Nigeria

Helleiner, G.K. (1966) Peasant Agriculture, Government and Economic Growth in Nigeria, Homewood ILL: Irwin

Mabogunje, A.L. (1972) Regional Mobility and Resource Development in Nigeria, Montreal: McGill-Queens University Press
Mellor, J.W. (1995) 'Introduction' in J.W. Mellor (ed.), Agriculture on the Road to Industrialisation, Baltimore: Johns Hopkins University Press

Mortimore, M. (2003) The Future of Family Farms in West Africa. What Can We Learn from Long-Term Data?, Drylands Programme Issue Paper 119, London: International Institute for Environment and Development (IIED)

Mortimore, M. (1989) Adapting to Drought: Farmers, Famines and Desertification in West Africa, Cambridge: Cambridge University Press

Mortimore, M. and Turner, B. (2005) 'Does the Sahelian Smallholder's Management of Woodland, Farm Trees, Rangeland Support the Hypothesis of Human-Induced Desertification?', Journal of Arid Environments 63: 567-95

Mustapha, A.R. (forthcoming) Zimbabwean Farmers in Nigeria: Exceptional Farmers or Spectacular Support?

Mustapha, A.R. and Meagher, K. (2001) Agrarian Production, Public Policy and the State in Kano Region, 1900-2000, Kano-Maradi Study of Long-Term Change: Niger-Nigeria Series, Working Paper 35, Crewkerne, UK: Drylands Research

Mustapha, A.R. and Meagher, K. (2000) 'Agrarian Production, Public Policy and the State in Kano Region, 1900-2000', Kano-Maradi study of long-term change: Niger-Nigeria Series Working Paper 35, Crewkerne: Drylands Research

OECD (2000) Preparing for the Future: A Vision of West Africa in the Year 2020, Paris: Organisation for Economic Cooperation and Development

Potts, D. (2012) Whatever Happened to Africa's Rapid Urbanisation?, London: Africa Research Institute

Prothero, R.M. (1959) Migrant Labour from Sokoto Province, Northern Nigeria, Kaduna: Government Printer

Rouch, J. (1956) 'Migrations au Ghana', [Migration in Ghana], Journal de la Société des Africanistes 36: 33-196

Tiffen, M. (1976) The Enterprising Peasant, London: Crown Agents

Udo, R.K. (1975) Migrant Tenant Farmers of Nigeria, Lagos: African Universities Press

World Bank (2007) World Development Report 2008 : Agriculture for Development, Washington DC: World Bank 